\title{
THE CHARTER: A PLEA FOR TOLERANCE
}

\author{
CAMIEL HAMANS
}

\begin{abstract}
This paper describes the background of the Charter for Regional and Minority Languages (1992). To explain why linguistic diversity became an issue in the last decades of the $20^{\text {th }}$ century, the paper goes back to the end of the $18^{\text {th }}$ and the $19^{\text {th }}$ century, a period in which nation building and homogenization were the main political issues in Western Europe. Since language was seen as nation binder language diversity was anathema. This led to language conflicts, which were sought to be solved by means of the Charter that promoted the acceptance of language diversity.
\end{abstract}

Key words: nationalism, one nation one language, diversity, tolerance, Charter for regional and Minority languages

\section{Introduction}

When in November 1992 the Council of Europe accepted the Charter for Regional and Minority Languages, it was three years after the Fall of the Berlin Wall and in the same year as Francis Fukuyama published his striking book The End of History and the Last Man. The Charter is an international convention meant to protect and promote languages used by traditional European (linguistic) minorities and which were often discriminated in the past. Hence, one may think that the Charter is one of the results of the increasing influence of Western liberal democracy with its focus on civil rights in the early ' 90 's of the $20^{\text {th }}$ century.

However, the Charter does not reflect the new wave of liberal democracy of the '90's as will be shown in this paper. The Charter is an attempt to settle linguistic conflicts that have arisen from $19^{\text {th }}$ century nationalism, as will be exemplified in the first part of this paper. In addition, it will be shown that the original aim of the Charter was not to resolve language conflicts in Central or Eastern Europe, but to put an 
end to long-known linguistic issues that play out in Western Europe. These conflicts are what will be dealt with in the second part.

In the third part of this paper it will be explained who the initiators of the linguistic minority debate in the European institutions were. The fourth and final part ends with a conclusion.

\section{The rise of the National language}

For centuries the status of languages was not a serious issue in Europe. Europe used to be a unstable patchwork of kingdoms, principalities, bishoprics, early republics, duchies, counties, small states and towns, all with their own authority structure, power, culture and dialect. There was still no question of overarching, national, languages. Although there have been attempts to come to standardization and to introduce a standard language in different countries and cultures since the Renaissance, one must wait till the very end of the $18^{\text {th }}$ and the beginning of the $19^{\text {th }}$ century before the issue of national languages became a point of debate.

Till the Renaissance Latin was the languages in which official correspondence took place, in which scholars communicated and in which god was glorified. However, from the $14^{\text {th }}$ century different vernaculars claimed their place. In Italy the 'questione della lingua', the problem which regional variant of Italian to choose, kept scholars and writers busy, till Pietro Bembo knew how to settle for archaic Tuscan in 1525. The founding of the Academia della Crusca in 1582/1583, which aimed at publishing an Italian dictionary based on this variety set the standard for the later national language (Perceval, 1995: 150; and Richardson 1995: 155).

In France King Francis I issued the Ordonnance de Villers-Cotterêts in 1539, by which he called for the use of French instead of Latin in all legal acts. Within a few decades a number of French grammars and dictionaries were compiled and published. The names of the $16^{\text {th }}$ century printers and scholars, father and son, Robert and Henri Estienne became household names in French grammatical studies (Kibbee, 1995: 161-166). In Germany the Bible translation by Martin Luther, published between 1522-1534 advocated the right of the German vernacular eloquently. In England the Book of Common Prayer 1549 did the same for English (Kelly 1995, 423). In the Netherlands the publication of the Twespraeck van de Nederduitsche letterkunst of vant Spellen en de Eygenschap der Nederduitschen Taals 'Dialogue about the Grammar of Dutch or about the orthography and the qualities of the Dutch Language' by a literary society in 1584 had a similar effect (Van der Wal and Van Bree, 1992: 186-188).

However, all these discussions were restricted to the few literate members of the society. Neither the standardized chancery dialect of France nor the supra-regional German of Luther could be prescribed. The 'educated' vernacular remained the lan- 
guage of a small elite. In addition, the debate was about the status of the 'national' vernacular compared to Latin and about which norms and standards to be established for the different vernaculars not about the priority of a national language above its dialects or about the assumed unifying power of a national language. The debate about these issues started around the turn of the $18^{\text {th }}$ and $19^{\text {th }}$ century.

\subsection{Germany}

In Germany, which was still not a nation state but a cultural gathering of principalities, small states, towns and regions, the philosopher Johann Gottfried Herder (1744-1803) claimed that there was a special one to one relation between nation and language. Herder, who is seen as the father of romantic nationalism, introduced the term Volksgeist 'national spirit' and in this spirit language played an essential role, since it was the language that united all German speaking peoples.

Herder was one of the first theorists who stressed the importance of nationhood. By nation, he meant a national state with one people, that shared the same Volksgeist and thus with one and the same culture (Patten, 2010). Language and cultural traditions were essential for the formation of a nation.

[I]n a passage written in the 1760s Herder treated language as the quintessential characteristic of nationhood, saying that 'truth, beauty, and virtue - became as national as language was' [...]. In the Ideas he wrote that every people has its language [...], and added that nations have been separated from one another by language [...]. And in a 1795 text appended to the Letters on the Advancement of Humanity, he declared that 'whoever was raised in the same language, who poured his heart into it, and learned to express his soul in it, he belongs to the nation (Volk) of this language (Patten, 2010: 667).

In his Abhandlung über den Ursprung der Sprache 'Treatise on the Origin of Language' (1772), an essay about the first human language, he claimed that the different languages are necessary to keep the different tribes in which groups of human beings lived together ${ }^{1}$. A one to one relation between language (Sprache) and people (Volk) is an immediate consequence of this view. Therefore, Germany with its unique German Volksgeist based on a shared tradition and a common language could and should become united.

\footnotetext{
${ }^{1}$ According to Herder (1772), the second natural law says that "The human being is in his destiny a creature of the herd, of society. Hence the progressive formation of a language becomes natural, essential, necessary for him." Therefore, language really becomes tribal core (Stamm). The third law explains why there are so many different tribes and languages: "Just as the whole human species could not possibly remain a single herd, likewise it could not retain a single language either. So there arises a formation of different national languages." (Forster 2002, also available via https://www.marxists. org/archive/herder/1772/origins-language.htm)
} 
The desired goal of unification rests upon discursive unity, provided by the authority of tradition and a unified adherence to the national spirit. And here too, linguistic homogeneity is a necessary condition: "One people, one fatherland, one language" [...]. In Herder's vision, a viable polity can only be founded on a national language resistant to the penetration of foreign tongues (Bauman and Briggs, 2003: 193).

A few years after Herder passed away, the philosopher Johann Gottlieb Fichte (1762-1814), one of the main figures in German idealism and one of the founders of (German) political nationalism, presented a series of lectures in Berlin: Reden an die Deutsche Nation 'Addresses to the German Nation' (1807/1808). In these lectures, which he delivered in a French-occupied Berlin, he made an appeal to the German nation to unite. Germans shared a common language and consequently they should use their patriotism to unite the country, they should form one nation. Subsequently he wanted this new Germany to use its special virtues to bring the fruits of Enlightenment, which in his opinion were spoiled by the French, to the world.

In his Addresses to the German nation Johann Gottlieb Frege (...) first gave philosophical authority to the claim of the identity of nation, state and language: "It is incontestably true, whatever a particular language is found, a separate nation exists which is entitled independently to take charge of its own affairs and govern itself (Coulmas, 1995: 60/61).

German was not only a most outstanding language, its tradition made it more authentic than other languages, especially better than French.

Living languages were those with an unbroken and 'pure' tradition, such as German. Dead languages, on the other hand, were languages with mixed and broken-off traditions like Latin, Celtic, French or English. [...] German was alive and more authentic, incorporating, as it did, the spirit of the Urvolk. The Germans, he said, speak 'a language which is shaped to speak the truth (Coulmas, 1995: 61).

Germans share a Germanness that results from the unbroken tradition of the common language and that goes back to the early days of European history, whereas a language such as French goes back on Latin, a different language. Therefore he calls the history of French broken.

Fichte located Germanness in the supposed continuity of the German language and based it on Tacitus, who had hailed German virtues in Germania and celebrated the heroism of Arminius $^{2}$ in his Annales (World Heritage Encyclopedia) ${ }^{3}$.

\footnotetext{
${ }^{2}$ Arminius (18/17BC-AD21) was the chieftain of a German tribe who led the German tribal coalition that defeated the Roman legions in the Battle of the Teutoberg Forest (AD 9).
} 
The emphasis of Herder, Fichte and their followers on the relation between nation-state and language made it almost impossible to have an eye for diversity. It was the national language that was celebrated, not regional variants, dialects or deviant minority languages.

\subsection{France}

The status and the value of the national language were not only at issue in Germany; a bitter debate about language and dialect was prevalent in Revolution's France. The French Revolution proclaimed the equality of all citizens. Therefore, they all should be able to use the same language to exercise their civil rights and to check the power. 27 January 1794 Bertrand Barère (1755-1841), member of the Comité de la salut public 'Committee of Public Safety', addressed and presented his report sur les idomes 'about the dialects'.

Citizens, the coalition tyrants have said: ignorance has always been our most powerful auxiliary; let us keep the ignorance; it makes the fanatics, it multiplies the counterrevolutionaries; let us turn back the French towards barbarism: let us serve poorly educated peoples or those who speak an idiom different from that of public instruction. The committee heard this conspiracy of ignorance and despotism.

Today I call your attention to the most beautiful language of Europe, the first which has frankly devoted the rights of man and of the citizen, the one which is charged with transmitting to the world the most sublime thoughts of freedom and the greatest expectations of politics. [...]

It is necessary to popularize the language, it is necessary to destroy this aristocracy of language which seems to establish a polite nation in the middle of a barbarous nation.

We have revolutionized government, laws, morals, customs, costumes, commerce, and even thought; so, too, let us revolutionize language, which is their daily instrument. $[\ldots]$

[I]n the monarchy, every house, every commune, every province, was in some sort an empire separated from morals, habits, laws, customs, and language. The despot needed to isolate the peoples, to separate the countries, to divide the interests, to prevent the communications, to stop the simultaneity of the thoughts and the identity of the movements. Despotism maintained the variety of idioms: a monarchy must resemble the tower of Babel; there is only one universal language for the tyrant: that of the force to have obedience, and that of the taxes to have money.

In the democracy, on the contrary, the surveillance of the government is entrusted to every citizen; to keep an eye on him one must know him, one must above all know his language. $[\ldots]$

\footnotetext{
${ }^{3}$ http://central.gutenberg.org/articles/eng/Fichte

${ }^{4}$ This committee was in fact the highest executive power in the years 1793 and 1794.
} 
Citizens, the language of a free people must be one and the same for all (Barère, $1794)^{5}$.

A few months later, 4 June 1794, Abbé Gregoire also presented a report, this time to the National French Convention, the parliament. This report, Rapport sur la Nécessité et les Moyens d'anéantir les Patois et d'universaliser l'Usage de la Langue française 'Report on the necessity and means to annihilate the regional languages and to universalize the use of the French language' claimed that only $20 \%$ of the French people was able to speak and understand the language as it was spoken in Paris and in the Convention, which prevented the other 80 percent from exercising their rights, but even more so in formulating their thoughts. Les Patois, a term for regional languages as well as for dialects, were seen as backward, as belonging to the days of tyrannical monarchs, whereas the national language French was the language of freedom. Gregoire was of the opinion that the Revolution could only succeed when all the French people would speak this language of freedom. At the same time he was sure that the Revolution would bring the national language to all villages and homes, because all soldiers who returned to their hearths would take the national language home. Therefore, he believed that in the end France would be united by a unified language and that in this way the people would be elevated.

[W]ith thirty different patois, we are still, for language, at the tower of Babel, while, for freedom, we form the vanguard of the nations. [...]

${ }^{5}$ Citoyens, les tyrans coalisés ont dit : l'ignorance fut toujours notre auxiliaire le plus puissant; maintenons l'ignorance; elle fait les fanatiques, elle multiplie les contre-révolutionnaires; faisons rétrograder les Français vers la barbarie: servons-nous des peuples mal instruits ou de ceux qui parlent un idiome différent de celui de l'instruction publique. Le comité a entendu ce complot de l'ignorance et du despotisme.

Jeviens appeler aujourd'hui votre attention sur la plus belle langue de l'Europe, celle qui, la première, a consacré franchement les droits de l'homme et du citoyen, celle qui est chargée de transmettre au monde les plus sublimes pensées de la liberté et les plus grandes spéculations de la politique. [...]

Il faut populariser la langue, il faut détruire cette aristocratie de langage qui semble établir une nation polie au milieu d'une nation barbare. Nous avons révolutionné le gouvernement, les lois, les usages, les mœurs, les costumes, le commerce et la pensée même; révolutionnons donc aussi la langue, qui est leur instrument journalier. [...]

[D]ans la monarchie même chaque maison, chaque commune, chaque province, était en quelque sorte un empire séparé de mœurs, d'usages, de lois, de coutumes et de langage. Le despote avait besoin d'isoler les peuples, de séparer les pays, de diviser les intérêts, d'empêcher les communications, d'arrêter la simultanéité des pensées et l'identité des mouvements. Le despotisme maintenait la variété des idiomes : une monarchie doit ressembler à la tour de Babel ; il n'y a qu'une langue universelle pour le tyran: celle de la force pour avoir l'obéissance, et celle des impôts pour avoir de l'argent.

Dans la démocratie, au contraire, la surveillance du gouvernement est confiée à chaque citoyen ; pour le surveiller il faut le connaître, il faut surtout en connaître la langue. [...] Citoyens, la langue d'un peuple libre doit être une et la même pour tous (Barère,1794). 
But at least we can standardize the language of a great nation, so that all the citizens who compose it can without hindrance communicate their thoughts. This enterprise, which was not fully executed by any people, is worthy of the French people, who centralize all the branches of social organization and who must be jealous of rather devoting themselves, in a single and indivisible Republic, to the unique and invariable usage of the language of freedom. [...]

I believe I have established that the unity of the idiom is an integral part of the revolution [...]. In general, in our battalions we speak French, and this mass of republicans who will have contracted the use will spread it in their homes. By the effect of the revolution, many of the above-mentioned townspeople will go to cultivate their lands. There will be more ease in the countryside; we will open canals and roads; for the first time, effective measures will be taken to improve local roads; the national holidays, by continuing to destroy the gambling dens, games of chance, which have so much afflicted families, will give the people pleasures worthy of it: the combined action of these various operations must turn to the profit of the French language. [...]

I would like all the municipalities to admit in their discussions the exclusive use of the national language; I would like a systematic plan to repudiate the absurd denominations of squares, streets, wharves and other public places. [...]

It is time for the deceitful style, for the servile formulas to disappear, and for the language everywhere to have the character of veracity and laconic pride which is the prerogative of the republicans. A tyrant of Rome formerly wished to introduce a new word; it failed because language legislation was always democratic. It is precisely this truth that guarantees you success. Prove to the world that in the midst of political storms, holding the rudder of the State with a sure hand, nothing that interests the glory of the nation is foreign to you. [...]

If the National Convention welcomes the views I submit to it on behalf of the Committee of Public Instruction, and if these views will be encouraged by its consent, we will invite citizens who have deepened the theory of languages to help to perfect our own usage and will invitate all citizens to universalize its use. The nation, entirely rejuvenated by your care, will triumph over all the obstacles and nothing will slow the course of a revolution which is to improve the lot of the human species [...] (Gregoire, 1794). ${ }^{6}$

\footnotetext{
${ }^{6}$ Ainsi, avec trente patois différents, nous sommes encore, pour le langage, à la tour de Babel, tandis que, pour la liberté, nous formons l'avant-garde des nations. [...]

Mais au moins on peut uniformiser le langage d'une grande nation, de manière que tous les citoyens qui la composent puissent sans obstacle se communiquer leurs pensées. Cette entreprise, qui ne fut pleinement exécutée chez aucun peuple, est digne du peuple français, qui centralise toutes les branches de l'organisation sociale et qui doit être jaloux de consacrer au plutôt, dans une République une et indivisible, l'usage unique et invariable de la langue de la liberté. [...]

Je crois avoir établi que l'unité de l'idiome est une partie intégrante de la révolution [...].

En général, dans nos bataillons on parle français, et cette masse de républicains qui en aura contracté l'usage le répandra dans ses foyers. Par l'effet de la révolution, beaucoup de ci-devant citadins iront cultiver leurs terres. Il y aura plus d'aisance dans les campagnes ; on ouvrira des canaux et des routes ; on prendra, pour la première fois, des mesures efficaces pour améliorer les chemins vicinaux ; les fêtes nationales, en continuant à détruire les tripots, les jeux de hasard, qui ont désolé tant de
} 
While German was seen as a means of nation-building in Germany, French was considered as a means of democratization but even more as a means to uplift people, to get the people out of their backlog. Or as La Gazette du Midi (1833) wrote: "The 'patois' is superstition and separatism, the French must speak the language of freedom"” (Adomié, 2013: 24). Consequently, the status of patois was very low. Dialects, regional variants and minority languages were seen as inferior. This ideological stance remained the linguistic and educational program for France even after the time of the Revolution.

In the 1880's Jules Ferry, minister of education, reformed the French school system. He founded l'École de la République 'the School of the Republic', the public school. This type of school aimed at achieving equality among the French citizens. Therefore, a uniform school system was needed in which only one language could get a place, and this was of course the official and national language (Van der Elst and Van Rootselaar, 2004). Patois should be banned from school. An inspection report from 1893 called patois the worst enemy of education in primary schools (Adomié, 2013: 24). No wonder that in the French schools signs appeared on which one could read 'no spitting or speaking patois (Occitan or Breton etc.) ${ }^{8}$. School rules prohibited speaking patois, even during leisure time. ${ }^{9}$ In his 1998 parliamentary

familles, donneront au peuple des plaisirs dignes de lui : l'action combinée de ces opérations diverses doit tourner au profit de la langue française. [...]

Je voudrais que toutes les municipalités admissent dans leurs discussions l'usage exclusif de la langue nationale $;[\ldots]$ je voudrais qu'un plan systématique répudiât les dénominations absurdes des places, rues, quais et autres lieux publics. [...]

Il est temps que le style mensonger, que les formules serviles disparaissent, et que la langue ait partout ce caractère de véracité et de fierté laconique qui est l'apanage des républicains. Un tyran de Rome voulut autrefois introduire un mot nouveau ; il échoua, parce que la législation des langues fut toujours démocratique. C'est précisément cette vérité qui vous garantit le succès. Prouvez à l'univers qu'au milieu des orages politiques, tenant d'une main sûre le gouvernail de l'État, rien de ce qui intéresse la gloire de la nation ne vous est étranger. [...]

Si la Convention nationale accueille les vues que je lui soumets au nom du Comité d'instruction publique, encouragés par son suffrage, nous ferons une invitation aux citoyens qui ont approfondi la théorie des langues pour concourir à perfectionner la nôtre et une invitation à tous les citoyens pour universaliser son usage. La nation, entièrement rajeunie par vos soins, triomphera de tous les obstacles et rien ne ralentira le cours d'une révolution qui doit améliorer le sort de l'espèce humaine. [...] (Grégoire, 1794).

${ }^{7}$ Le patois porte la superstition et la séparatisme, les Français doivent parler la langue de la liberté

${ }^{8}$ Il est défendu de parler breton/occitan/patois et de cracher à terre. See for instance, retrieved 7.8.2017 https://lachouetteaveuglesite.wordpress.com/2016/05/25/il-est-defendu-de-parler-breton-et-decracher-a-terre/

${ }^{9}$ See for instance : Extrait du Guide des Ecoles primaires (1835, article 22), retrieved 6.2.2018, from https://books.google.nl/books?id=y0hq1q0J2kcC\&pg=PA8\&lpg=PA8\&dq=il+est+defendu+de+par ler+patois+pendant\&source=bl\&ots=zcPPAnTl10\&sig=wgvYtqfbhLBhVcewdx- 
report about regional languages and cultures Bernard Poignant confirms that it was still the practice in school to punish children for speaking patois.

Since the French culture was the most prestigious culture in the $19^{\text {th }}$ and early $20^{\text {th }}$ century in most parts of Europe, this French ideological position was followed widely. Dialects, regional and minority languages were considered retarded and did not need any protection. To the contrary their use should be contested, at least at school. At some secondary schools in the southern provinces of the Netherlands, for instance, it was forbidden to speak the local dialect till the 1930's (Hamans, 2015: 60). It took, except for the use of Frisian, until 1975 before the first non-standard language, the dialect of the city Kerkrade, got a formal role at a Dutch school (Hagen, Stijnen and Vallen, 1975).

\section{Language conflicts}

The two examples discussed above show how a national language ideology came up in the wake of the $18^{\text {th }}$ century and how this ideology became predominant. The $19^{\text {th }}$ and first half of the $20^{\text {th }}$ century is the time in which uniform, standardized national languages were promoted. Apart from a romantic interest in dialects as testimonies of earlier stages of the language or as part of folklore, there was no real interest in other language variants than the prestigious national languages. In this era of nationalism a linguistic homogeneity myth (Watts, 2012) prevailed in Western Europe and was considered not only as plausible but even as universally valid. Nations were or should be homogeneous, which implied that the people as well as their language should be homogeneous ${ }^{10}$. Even in two respects: the national language should only consist of a uniform Kultursprache with standards and norms and without variation and secondly, next to this Kultursprache there was no room for other languages or language varieties. This necessarily led to conflicts in regions where another language than the promoted and dominant national language was spoken. Only a few of these language conflicts will be mentioned here.

\subsection{Frisian}

In the early Middle Ages Frisian was spoken along the continental coasts of the North Sea. In the course of history this language, which differs considerably from Dutch and which historically belongs to a different branch of West Germanic than

SLk7EBDQ\&hl=nl\&sa=X\&ved=0ahUKEwjavJjLjM7ZAhVIW8AKHXr6DUkQ6AEIKDAA\#v=onepage \& $\mathrm{q} \& \mathrm{f}=$ false

${ }^{10}$ Unfortunately, this idea has not disappeared with the $19^{\text {th }}$ and first half of the $20^{\text {th }}$ century, as the situation in the post-Yugoslavian countries, Serbia, Croatia, Bosnia and Montenegro show. 
Dutch and Low German, has been reduced to a small area that of the Dutch province of Friesland. Since Dutch was the official language of the Kingdom of the Netherlands, Dutch automatically became the official language in Friesland too. However, only well-educated people in $19^{\text {th }}$ century Friesland spoke Dutch. Frisian was still the vernacular. This prompted some people in Friesland to engage in their own language. This happened already in the 1820's and ' 30 's and was the starting point of a Frisian movement that is still active. Most of the early activities of the Frisian movement consisted of publication of Frisian literature, linguistic studies, designing an orthography and compiling dictionaries. However, from the 1930 onwards a young generation of Frisian activists demanded a place for Frisian in social life, in education, in administration and in court. The first steps were taken with changes in education legislation in 1937 and 1948. The opportunity was offered to teach Frisian. However, full recognition of Frisian was not forthcoming. It was only after public riots in November 1951 that the Dutch government awoke with a start. However, it still took till 1989 before the province of Friesland, Fryslân, was recognized as a bilingual region with special measures for the protection and the promotion of it language. It was only in 2014 that a special law came into force that allowed the use of Frisian in all domains next to Dutch. ${ }^{11}$

\subsection{Flanders}

In Flanders the situation was different. From 1830, Flanders was part of the new state of Belgium. In the south of Belgium French was the daily language, whereas in Flanders the majority spoke different Dutch dialects, usually called Flemish. French was the language of prestige in the whole kingdom, so the higher social classes in Flanders also spoke French. Quite often they gave up their local, Flemish, dialect completely. French became the only accepted language in government and in the army, and thus also became the language of education. Already in 1840, a group of prominent people from Flanders protested the hegemony of French. They started a petition in which they asked for recognition of Dutch in education, administration and court in Flanders ${ }^{12}$. The francophone prime minister Rogiers answered that a monolingual Belgium, with French as its official language, was a necessity. The protesters did not accept this and continued to fight for the recognition of their language and for equal rights for its speakers. This led to a victory of a Flemish coali-

\footnotetext{
${ }^{11}$ For a more detailed account about the language conflict in Friesland, see Hamans (2016, 54-57).

${ }^{12}$ From 1815 till 1830 Belgium was part of the Netherlands. Based on the language policy of the then king William I Dutch had been the language of education, administration and court in Flanders during this period. The memory thereof my explain why the Flemish language struggle started so early (Hamans 2016, 46-51).
} 
tion in the local Antwerp elections of 1866. Consequently, Dutch became the language of the local administration in this city.

However, this success of the Flemish Movement did not change the national language situation. In 1860 two Flemish men were sentenced for murder and beheaded after a completely French speaking court trial. Even their lawyers spoke French only. A year later it turned out that the two were innocent. Twelve years later, a monolingual Dutch-speaking worker, wanted to declare the birth of his son. He only knew Dutch, so he wanted to fulfill his duty in Dutch, which turned out to be impossible. He was even fined by the court. As can be imagined, this incident sparked much commotion. Protest marches and riots were the result. The government reacted with a first language law in 1873.

The law did not end the language conflicts, especially not because the Frenchification of social life in Flanders continued. French remained not only the language of the elite but also a language with a superior status. So, everybody in Flanders who wanted to make a career had to learn French. French was the dominant language. Unfortunately, the top of the Roman Catholic Church in Belgium was francophone and did not support the case of Dutch. The leader of the Belgian Roman Catholic Church, cardinal Mercier, still claimed that Dutch was not a language of science in 1906. Therefore, Dutch never could become a language of higher education, according to him.

Despite all improvements in legislation, it lasted till 1968 that the University of Leuven, which is in the Dutch speaking part, accepted Dutch as the language of education. A protracted and violent student revolt was necessary before French was abolished as the first language of education. Still, not all language conflicts are solved. There are still problems and sometimes protest marches, violent protests and resistance and political issues. ${ }^{13}$

\subsection{Spain}

Spain, now known for its conflicts between the region of Catalonia and the central authorities in Madrid, was the first European country that recognized the identity of regional minorities. It were the leftist leaders of the Second Spanish Republic (1931-1936) that introduced the first statutes of autonomy for some regions in which the special place of their different languages was recognized.

In the second half of the XIX the century, a growing regional cultural and literary romanticism appeared, also in the regions where a vernacular language was spoken. At the same time, a social and cultural recognition of the specific identities of the territories

\footnotetext{
${ }^{13}$ For a short overview of the Belgian language struggle, see Hamans $(2016,48-51)$ and the literature quoted there.
} 
concerned developed and triggered a process towards a new and different territorial organisation. The political battles, and above all the civil wars of the XIXth and XXth centuries prevented a harmonious convergence of the two positions. During the Second Spanish Republic (1931-1936), a statute of autonomy was approved by the Spanish Parliament for Catalonia in 1931 and for the Basque country in October 1936. In Galicia the process was not completed owing to the dramatic events of the 1936-1939 Civil War. The Franco regime represents a brutal interruption of the process of recognition and use of traditional regional or minority languages of Spain that had just started (Expert's Report Spain, 2005: 5).

However, when the Franco regime seized power in 1939, the process of recognition of (linguistic) minority rights stopped abruptly. The unity of the country became the main goal again. Autonomy was anathema. Anything which could be interpreted as an expression of minority rights was oppressed. This lasted till the end of Franco's regime in 1975 and the first democratic elections two years later. The oppression must be taken literally. The Catalan leader Lluis Companys was tortured and executed in 1940. ${ }^{14}$ Distribution of books printed in Catalan was forbidden. Priests who spoke Galician to a foreigner were banished to small remote hamlets in the mountains, as the Dutch geologist Kroonenberg (2014: 290) experienced. The Basque linguist Itziar Laka told how her grandmother had to spend a night in jail, since she had dared to speak Basque to an acquaintance from a village who did not speak Spanish (Hamans, 2015: 62).

The effect of this new policy was the rise of protest movements. In the Basque country, for instance, Euskadi Ta Askatasuna 'Basque Homeland and Freedom', ETA, was founded in 1959. The protests of the ETA were not limited to verbal statements. In the almost fifty years of ETA resistance more than 800 people got killed. $^{15}$ The protest from the side of the Catalonian and Galician autonomy movements was of a less terrorist character, although these groups also committed bomb attacks. The Catalan movement Terra Lliure or TLL 'Free Land' was active between 1978 and 1995. Between 1980 and 1985 TLL committed more than fifty bomb at$\operatorname{tacks}^{16}$, fortunately without much victims; the Galician Loita Armada Revolucionaria, LAR, 'Revolutionary Armed Struggle' and its successors not only aimed at autonomy or independence, but also had an extreme leftist signature. It specialized in robberies and bombings ${ }^{17}$

The internal conflicts in Spain were not exclusively linguistic in nature, but the prohibition of their own language played an enormous role in the struggle for autonomy.

\footnotetext{
${ }^{14}$ https://www.biografiasyvidas.com/biografia/c/companys.htm

${ }^{15}$ Winkels (2017)

${ }^{16}$ Retrieved 8.1.2018 from https://en.wikipedia.org/wiki/Terra_Lliure

${ }^{17}$ Retrieved 8.1.2018 from https://en.wikipedia.org/wiki/Loita_Armada_Revolucionaria
} 


\subsection{Post-Habsburgian language conflicts}

Linguistic conflicts were not restricted to the Low Countries and Spain; at the Austrian-Italian border there were also serious language clashes. The region, which was part of the Austro-Hungarian Empire until it was ceded to Italy at the end of the First World War, is supposed to be bilingual, a dual identity reflected in its name Alto Adige in Italian and Südtirol in German. After the Second World War, the Austrian and Italian governments signed an agreement, the so-called Gruber - De Gasperi agreement, in which German was recognized as an official language in this region. However, a part of the German speaking majority of Südtirol did not feel satisfied with the agreement. They fought for more autonomy and more language rights. After unsuccessful mediation of the UN in 1960/61 heavy terrorist attacks took place. The debate lasted for almost a decade, till finally in 1969 a compromise was reached. However, it took another good twenty years before Austria and Italy were able to inform UN in 1992 that the pending problem of Alto Adie/ Südtirol had come to an end (Von Hartungen, 2002: 14-19). Unfortunately, an imprudent remark by an inexperienced Austrian politician sparked alarm in Italy recently. ${ }^{18}$

The most post-Habsburgian linguistic problems, however, emerged from the Treaty of Trianon (1920). This treaty, which was the peace agreement to formally end the First World War between the Allies and Hungary, defined the new borders of Hungary. The effect was that one third of the speakers of Hungarian lived outside Hungary from then on. Hugh Hungarian speaking minorities lived and live in Romania, Czechoslovakia (now Slovakia) and Yugoslavia (now Serbia) (Fenyvesi, 1998: 145). The possible problems and conflicts which could have resulted there from did not attract much reaction in Western Europe. After the establishment of NATO in 1949 and the subsequent establishment of the Warsaw Pact Europe was divided in two areas of interest. Western Europe concentrated on itself and the US, whereas Central Europe kept its eyes focused on Moscow.

Sometimes the rights of linguistic minorities were used as showcase in CentralEurope, since these regimes wanted to show how they respected civil rights and how their most perfect system excluded discrimination and deprivation. For instance, the rights of the Sorbs were explicitly recognized in the constitution of the DDR ${ }^{19}$. There were special schools for Sorbs, there were a few Sorbian newspapers and street signs and signposts were in two languages. However, since minorities usually differ in more respect than in language only - for instance the Sorbs were Roman Catholic whereas the rest of the DDR was Lutheran, if they were religious at all there was full ground for deviant behavior and therefore animosity. The communist

\footnotetext{
${ }^{18}$ Retrieved 8.1.2018 from http://www.adnkronos.com/aki-en/politics/2017/12/21/post-war-accordalto-adige-upheld-italy-tells-austria_HcVnlBJazva2gS7fiOQ51J.html

${ }^{19}$ Retrieved 8.1.2018 from http://minorityrights.org/minorities/sorbs/
} 
regimes which took over power in Central Europe after the Second World War stressed the equality of the people and did not allow protests or insurgent movements. So, it was only after the Fall of the Berlin Wall in 1989 that the first ideas about linguistic rights and autonomy were heard.

Moreover, one should not forget that several governments in Central Europe just wanted to stress the homogeneity of their countries. Before the Second World War, Central Europe used to be a patchwork of minorities. After the ethnic cleansing by the Germans and the post-war governments the new regimes wanted to stress their new unified national character. Therefore, the centralized governments only accepted a few well recognizable minorities. All the other groups were forced to give up their ethnic identity and language. For instance, the Polish government did not want to recognize Kashubian ${ }^{20}$. The language was considered to be a Polish dialect and the culture was seen as mere folklore. It was even claimed that the Kashubians had behaved treacherously during the second World War, because of the special treatment they received from the Nazi's, since the German occupiers assumed a certain kinship between Kashubian and German because of the great number of Low German loanwords. This alleged unpatriotic behavior was an extra argument not to grant them any special rights. ${ }^{21}$

After the Fall of the Berlin Wall, the rapprochement to Western-Europe and the membership of the European Union in 2004 the issue of minorities and their languages became negotiable. The Polish Act on National and Ethnic Minorities and on the Regional Languages (2005) enumerates a great number of ethnic and national minorities and their languages and also recognizes Kashubian as a regional language $^{22}$. However, the position of Silesian is still a matter of debate.

However, nobody in Western Europe bothered about the problems of linguistic minorities in Central or Eastern Europe till the Fall of the Berlin Wall in 1989. The

${ }^{20}$ Kashubian is a West-Slavic language, spoken in North-Central Poland. The language belongs to the same West-Slavic subgroup as Polish, but is much more influenced by Low German, Polabian and Old Prussian (Stone 1998, 49-50).

${ }^{21}$ At a conference on minority languages in Europe in Galway in 1986 a well-known Polish phonologist claimed there were absolutely no linguistic minorities in Poland. "In Poland their live only Poles and they all speak Polish, with different accents, but it is all Polish. There are no minorities and no regional or minority languages." When asked what he thought about Kashubian, he called it a Polish accent (p.c. Anders Ahlqvist).

${ }^{22}$ This Act makes a clear distinction between national and ethnic minorities. Examples of the first group are Czechs, Germans, Slovaks and Jews, whereas among others Roma and Tartars are considered to belong to ethnic minorities. The languages spoken by these two groups of minorities are called minorities languages. The speakers of these languages have the right to use their language in public life, the authorities have the duty to support these languages.

Next to these minority languages the Act (art. 19.2) also recognizes a regional language, Kashubian. The rights and obligations associated with this recognition are similar to that of the minority languages (Pisarek 2011). 
focus of the debate was on the vehement and often violent linguistic conflicts in Western-Europe. That should not surprise either, because the starting point of the debate was in the Council of Europe, the body for the promotion of democracy and civil rights in Europe. Until the fall of the Berlin Wall, the countries of Central- and Eastern-Europe were not members of the Council because of the very limited democratic state of their governments and their lack of respect for civil rights ${ }^{23}$.

\section{Initiatives}

The 1992 Charter for regional and Minority Languages did not come out of the blue but is the result of a discussion of decades. Some aspects of this discussion will be highlighted here in order to show what the initiators aimed at.

\subsection{Precursors of the Charter}

It was in the Council of Europe that the debate about the rights of minorities started. One should not confuse the Council of Europe and the EU, European Union. The Council of Europe is based in Strasbourg, was founded in 1949 and now has 47 member states. The work of the Council of Europe concentrates on the state of law, democracy and human rights. ${ }^{24}$ It is therefore not at all surprising that the rights of (linguistic) minorities were studied and discussed in committees of this Council.

One of the first initiatives was Resolution 136 on the 'Position of national minorities in Europe ${ }^{25}$ adopted by the Parliamentary Assembly in October 1957. The resolution was preceded by a report drafted by the Belgian socialist and former minister of justice, Henri Rolin (1891-1973). The report and the resolution did not deal with linguistic rights specifically but asked for attention for the rights of 'population groups conscious of belonging to a national minority in which another Member State is interested', such as the Danish speaking minority in Germany or the German speaking minority in Denmark. The Resolution had hardly any effect. Therefore, the Parliamentary Assembly adopted Recommendation 285, in which a committee of experts was asked to draft an article which would guarantee national minorities several rights in 1961. However, the Assembly was again not successful in its endeav-

${ }^{23}$ The Explanatory Report to the European Charter for Regional and Minority Languages by the Council of Europe explicitly states that the Charter was drafted before 'the dramatic changes in central and eastern Europe' and conceived and presented its draft in the light of the needs of the countries which at that time were already members of the Council of Europe' (Explanatory report 1992, sub 12).

${ }^{24}$ For more and detailed information about the Council of Europe see: https://www.coe.int/en/web/ about-us/founding-fathers

${ }^{25} \mathrm{http}: / /$ assembly.coe.int/nw/xml/XRef/Xref-XML2HTML-EN.asp?fileid=15552\&lang=en 
ors. The Committee of Ministers of the Council opposed the initiative of the Assembly to introduce specific (linguistic) rights for minorities. Fortunately, the opposition of the ministers did not end the debate, although it took years before a positive result could be reached. In 1989 the Assembly adopted Recommendation 928 on 'Educational and cultural problems of minority languages and dialects in Europe' in which the Assembly encouraged the Committee of Ministers to consider implementation of measures that would protect linguistic diversity. This recommendation was a result of a report by the Catalan socialist Alexandre Cirici I Pellicer (1914-1983) ${ }^{26}$.

\subsection{Rise of sociolinguistics}

The discussion was not limited to the Council of Europe, not even to political or governmental institutions. Also in linguistics a debate about the value of nonstandard varieties a debate arose. The name of the father of sociolinguistics William Labov is connected with this discussion. Labov questioned the old prejudice that the non-standard American English spoken by people of colour was linguistically and logically inferior to the standard language. In his famous The Logic of Nonstandard English (1969) Labov showed that Black English, later called African American Vernacular English, was in no way inferior to standard English.

We came to the conclusion that there were big differences between black and white speech patterns, but that the main cause of reading failure was the symbolic devaluation of African American Vernacular English that was part of the institutionalized racism of our society, and predicted educational failure for those who used it. (Labov, 1969: 200)

Labov's strictly linguistic work fitted very well into the socio-political context of the late '60's and '70's of the last century, in which the civil rights movement was clearly heard (cf. Joseph, 2002: 66).

In the North American context, where over $10 \%$ of the population is of African ancestry, we should not forget the importance that was attached by the Kennedy and Johnson administration to the study of 'Black English' research, in which Labov was very prominent. (Koerner, 2001: 18)

Labov argued convincingly that all language varieties are equal from a linguistic point of view and that they all are languages in their own right. Due to the promotion of national languages which started around 1800 in Western Europe, and the subsequent processes of standardization the languages of the national elites became a token of national pride, that was increasingly seen as a national binder and thus as a variety above all others. Ideologically, above meant superior (cf. Milroy, 2001).

\footnotetext{
${ }^{26}$ It will probably not be a coincidence that parliamentarians from countries with minority problems raised this issue.
} 
The new discipline of sociolinguistics, which became almost immediately popular in European academic circles with the writings of Labov, but also through the pioneering and influential studies of Peter Trudgill and Lesley and James Milroy, opposed this superiority ideology. A standard national language was increasingly seen as just a variety from a linguistic point of view, albeit one that is socially privileged (cf. Trudgill, 1974). This new vision provided room for the equal rights of other language varieties.

\subsection{Role of the $\mathbf{E U}$}

After previous attempts in the Council of Europe, the European Parliament developed an interest in this problem. Immediately after its first direct election in 1979 the debate started. In the European Parliament, one of the three main institutions of the $\mathrm{EU}^{27}$, it were again two socialist members who demanded attention for the problems of minorities. Gaetano Arfé (1925-2007), an Italian historian and journalist, was the first to table a motion for resolution together with some Italian and French colleagues from his political group. Arfé asked for a Charter of Ethnic Minorities. A few weeks later a representative from a region with serious minority conflicts, Northern Ireland, the socialist John Hume (1937), later winner of the Nobel Prize for Peace because of his commitment to peace in Northern Ireland, proposed a Bill of Rights of the Regional Languages and Cultures of the [European] Community.

Although at first glance both motions for resolution seemed very similar, there was in fact a profound underlying difference in approach between them. Whereas the Arfé Motion for Resolution speaks of 'the demands for autonomy, of ethnic and linguistic minorities', the Hume Motion for Resolution side-steps issues such as ethnicity and autonomy and rather refers to 'this diversity' being 'again one of the main sources of the vitality, richness and originality of European civilisation (Ó Riagáin, 2001: 22).

Although Arfé became parliamentary rapporteur ${ }^{28}$ on the linguistic aspects of the minority issues, Hume's approach turned out to be more successful. The Preamble of the 1992 text of the Charter echoes Hume's wordings.

Considering that the aim of the Council of Europe is to achieve a greater unity between its members, particularly for the purpose of safeguarding and realising the ideals and principles which are their common heritage;

\footnotetext{
${ }^{27}$ The two other main institutions of the EU are the European Council and the European Commission.

${ }^{28}$ A parliamentary rapporteur is a Member of the European Parliament, MEP, who prepares a report about a certain issue or proposal for a parliamentary Committee he is a member of. After the committee has discussed, amended and accepted the report, it will be sent to the plenary meeting, where it is still the rapporteur who defends the report, http://www.europarl.europa.eu/news/en/headlines/eu-affairs/201503 28STO39002/from-rapporteur-to-coordinator-the-different-roles-taken-on-by-meps (retrieved 8.1.2018)
} 
Considering that the protection of the historical regional or minority languages of Europe, some of which are in danger of eventual extinction, contributes to the maintenance and development of Europe's cultural wealth and traditions ${ }^{29}$

Later initiatives, proposals, reports and recommendations for both the Parliamentary Assembly of the Council of Europe and the European Parliament (EU) were generally also prepared by politicians from regions with language conflicts, such as the Flemish nationalist Willy Kuipers (1937), the Catalan nationalist Pere Esteve I Abad (1942-2005) and Mark Killilea (1939), an Irish MEP, member of the centerright Fianna Fáil party and coming from the Gaelic speaking Galway County. ${ }^{30}$.

The pressure put on the European Commission led to the opening of a small budget line in 1982 and the establishment in the same year of a European Bureau for Lesser Used Languages, EBLUL, with national committees in all member states. In 2010 EBLUL was replaced by ELEN, European Language Equality Network ${ }^{31}$.

\subsection{The Charter}

All these initiatives finally resulted in the adoption of the European Charter for Regional and Minority Languages by the Committee of Ministers of the Council of Europe in 1992. The Charter was prepared by the Standing Conference of Local and Regional Authorities of Europe, the pan-European political assembly representing local and regional authorities from the 47 member states of the Council of Europe. Seven years later the Charter entered into force after enough, formally five but actually seven, member countries of the Council of Europe ratified it ${ }^{32}$.

The objectives and principles of the Charter are expressed in article 7 :

1. In respect of regional or minority languages, within the territories in which such languages are used and according to the situation of each language, the Parties shall base their policies, legislation and practice on the following objectives and principles:

a. the recognition of the regional or minority languages as an expression of cultural wealth;

b. the respect of the geographical area of each regional or minority language in order to ensure that existing or new administrative divisions do not constitute an obstacle to the promotion of the regional or minority language in question;

\footnotetext{
${ }^{29}$ For the full text of the Charter see: https://www.coe.int/en/web/conventions/full-list/-/conven tions/rms/0900001680695175

${ }^{30}$ See for a non-exhaustive list of initiatives Hamans (2006, 247-249).

${ }^{31}$ https://elen.ngo/

${ }^{32}$ For a full list of signatories and ratifications see: https://www.coe.int/en/web/conventions/fulllist/-/conventions/treaty/148/signatures?desktop=false
} 
c. the need for resolute action to promote regional or minority languages in order to safeguard them;

d. the facilitation and/or encouragement of the use of regional or minority languages, in speech and writing, in public and private life;

e. the maintenance and development of links, in the fields covered by this Charter, between groups using a regional or minority language and other groups in the State employing a language used in identical or similar form, as well as the establishment of cultural relations with other groups in the State using different languages;

f. the provision of appropriate forms and means for the teaching and study of regional or minority languages at all appropriate stages;

g. the provision of facilities enabling non-speakers of a regional or minority language living in the area where it is used to learn it if they so desire;

$h$. the promotion of study and research on regional or minority languages at universities or equivalent institutions;

i. the promotion of appropriate types of transnational exchanges, in the fields covered by this Charter, for regional or minority languages used in identical or similar form in two or more States

2. The Parties undertake to eliminate, if they have not yet done so, any unjustified distinction, exclusion, restriction or preference relating to the use of a regional or minority language and intended to discourage or endanger the maintenance or development of it. The adoption of special measures in favour of regional or minority languages aimed at promoting equality between the users of these languages and the rest of the population or which take due account of their specific conditions is not considered to be an act of discrimination against the users of more widely-used languages.

3. The Parties undertake to promote, by appropriate measures, mutual understanding between all the linguistic groups of the country and in particular the inclusion of respect, understanding and tolerance in relation to regional or minority languages among the objectives of education and training provided within their countries and encouragement of the mass media to pursue the same objective.

4. In determining their policy with regard to regional or minority languages, the Parties shall take into consideration the needs and wishes expressed by the groups which use such languages. They are encouraged to establish bodies, if necessary, for the purpose of advising the authorities on all matters pertaining to regional or minority languages.

5. The Parties undertake to apply, mutatis mutandis, the principles listed in paragraphs 1 to 4 above to non-territorial languages. However, as far as these languages are concerned, the nature and scope of the measures to be taken to 
give effect to this Charter shall be determined in a flexible manner, bearing in mind the needs and wishes, and respecting the traditions and characteristics, of the groups which use the languages concerned.

\section{Application of the charter}

This is not the place to describe extensively how the Charter is applied in different European countries. The reports of the triennial monitoring cycle - starting with a State Periodical Report, followed by a Committee of Experts' Evaluation Report and Comments from the National Government of the State under discussion on the Evaluation Report and concluded with a recommendation of the Committee of Ministers $^{33}$ - give information enough about the way the Charter is applied in the 25 European countries that ratified the Charter. However, one point here still requires attention. That is the way the Charter can be used to promote the identity of groups that consider themselves as a minority. This aspect will be exemplified with an explanation of the way in which the charter has been introduced in the Netherlands ${ }^{34}$.

The Charter (part 1, art. 1) only wants to support regional or minority languages, which are languages that are:

- traditionally used within a given territory of a State by nationals of that State who form a group numerically smaller than the rest of the State's population;

- different from the official language(s) of that State.

In addition regional or minority languages do

- not include either dialects of the official language(s) of the State or the languages of migrants ${ }^{35}$.

${ }^{33}$ See for these reports, comments and recommendations : https://www.coe.int/en/web/europeancharter-regional-or-minority-languages/reports-and-recommendations \#\{\%2228993157\%22:[3]\}

${ }^{34}$ For a more detailed sketch of the introduction of the Charter in the Netherlands, see Hamans (2006) and (2016).

${ }^{35}$ The Explanatory Report (1992, sub 15 and 31) is more explicit about the languages of migrants. In 15 the Report says that the Charter does not deal with the often non-European languages which have arrived with the recent migration flows often arising from economic motives (sub 15).In 31 the Report emphasises that the Charter 'is not to resolve the problems arising out of recent immigration phenomena (...) The Charter is not concerned with the phenomenon of non-European groups who have immigrated recently into Europe and acquired the nationality of a European State.' These explanations show clearly that the Charter wants to exclude non-European languages such as Turkish or Arabic. In the Baltic countries and Georgia the argument that the Charter does not deal with the language of (im)migrants is used to exclude Russian, the language of the former occupational power, from recognition. The argument is that Russians settlers arrived in these regions only recently, which is in the last two centuries. However much it is understandable that one would prefer not to grant rights to the language of the former occupier, the Explanatory Report shows clearly that this can not be done based on the formulation in part. 1 art. 1 of the Charter. 
The Charter does not want to define what a dialects is or what the difference between an official language and its dialects is. Moreover, the Charter does not provide definitions of a regional or minority language. In addition the Charter does not enumerate the languages spoken in Europe, that should be recognized according to the Charter. This is all done because of the great discrepancies between the opinions about minorities and their languages within the different European member states and to prevent a dispute between these different member states. It is up to the national States that ratified the Charter to 'register' the regional and minority languages they wanted to be recognized.

In the Netherlands, there was already an awareness that Frisian is different from Dutch as shown in 3.1 and that Frisian therefore needed a special status. So, at the moment the Dutch government wanted to ratify the Charter the authorities only thought about Frisian. All the other varieties, except Yiddish and Romany, were seen as Dutch dialects, which, because of that reason, did not qualify for recognition in terms of the Charter. However, an organisation of speakers of Low-Saxon, which is spoken in the eastern and north-eastern part of the country, did not agree and asked for recognition. It was not the Charter which did them realise that they spoke a vernacular which differs considerably from standard Dutch. There were already several associations of speakers of different Low Saxon varieties, which existed for many years, when in 1984 a twenty organizations joined together and formed Streektaalorganisaties Nedersaksisch Taalgebied, SONT, 'Regional language organizations Lower Saxon Language Area', which became a driving force behind the application for recognition. In addition, there was already a chair and an institute for Low Saxon at Groningen University from 1953 onwards $^{36}$. The speakers of Low Saxon did not ask for autonomy or a special position within the Netherlands. What they wanted was a clear recognition of their different linguistic status, which according to them is an important part of their, regional, identity. The main Dutch specialists in dialectology endorsed the position taken by SONT. In this way, the Dutch authorities gave way to the argumentation of SONT and accepted Low Saxon as a regional language, albeit with a lower status than Frisian.

This was not the end of the debate about recognition of language varieties in the Netherlands. In Limburg, the province in the South-East of the country - Maastricht is the capital - there also prevails the idea of speaking a different language. Dialectologists always considered the Limburg dialects as very special since they are tone languages (Gussenhoven 2000). A 'dialect' organization, Veldeke, was already founded in $1926^{37}$. Also Veldeke managed to mobilize the best-known specialist in Dutch dialectology. They acknowledged that the Limburg vernacular should not be seen as a linguistic variety, thus dialect, of the Dutch standard language. So, Lim-

\footnotetext{
${ }^{36}$ See for the history of the study of Low Saxon, http://www.sont.nl/, retrieved 8.1.2018.

${ }^{37}$ Retrieved 8.1.2018 from https://www.veldeke.net/organisatie/historie-2/
} 
burger got its recognition, albeit after the ratification and at the same level as Low Saxon.

These two recognitions led to more requests. Speakers of other varieties claimed that their vernacular was also not a dialect of standard Dutch. In addition, they claimed that their own language is a crucial part of their regional or local identity. These new applications caused a serious debate. Opponents argued among other things that the moment one claims a regional identity you have to give up your national identity. Especially in Belgium, where the language laws are partly based on numerical arguments, this could lead to losses. A speaker of Limburger, which is also spoken across the Belgian border, could not be counted as a speaker of Dutch anymore when Limburger would be recognized as a regional language in Belgium too.

This discussion, in which identity is crucial, has not yet come to an end. Van Hout a.o. (2018) argue that language can be essential for identity building. Therefore recognition as a regional or minority language is important. As a counter argument against the numerical argument they argue that the speakers of a minority of regional language are bilingual in the Netherlands and other European countries with a full fledged educational system. Consequently, they should also be seen as native speakers of Dutch. In addition, they argue that people have a multiple identity. They are not only Limburger but also Dutch, just as they are female, daughter, mother, sister and for instance teacher. The other side argues that it is a form of ridiculous and fashionable identity politics to consider each difference as essential. Especially, since recognition may have budgetary consequences.

What is in fact the essence of this discussion is the extent to which people want to go in tolerance. Some groups of people claim they are more or less special and want to be accepted as such, so want to be recognized, whereas others still argue more or less in favor of a presupposed homogeneity. The Charter was never meant to be used as a factor in identity politics - when the Charter was conceived and drafted in the 1980's there was no identity politics at all - however it can be used in this way, since the Charter is clear weapon against the presupposed homogeneity of languages and nations.

\section{Conclusion}

As will be clear from the objectives as presented in 4.4., the Charter was meant to protect, and subsequently to promote, languages which were endangered. The Charter wanted to support speakers of European languages who so far were not allowed to use their languages for public purposes and who therefore felt discriminated on the basis of their native language. 
In other words, the Charter aimed at supporting speakers of languages which had lost a war, such as the Spanish Civil War or the First World War as in Südtirol or had lost the fight for prestige as was the case in Belgium, the Irish Republic or in France, where regional languages had been tried to wipe out. The initiatives and proposals which preceded the Charter show clearly that the aim of the Charter was to settle existing linguistic conflicts in Western Europe and to put an end to conflicts of an often-violent nature. The Charter attempts to repair the damage that 19th century nationalism has caused to non-national languages in Western-Europe.

That the Charter now can be applied to countries in Central and Eastern Europe with their specific problems was not foreseen (see fn 23). It may be an asset, but it never was its goal. In addition, the Charter has not been drawn up either to be used as a factor in identity politics. That the text of the Charter can also be used for this purpose proves the flexibility of this legal text.

What has been shown here is that the European policy towards languages changed dramatically in 200 years: was the focus around 1800 still on the promotion of national languages and as a consequence at the destruction and erasure of regional and minority languages, within two hundred years the situation changed completely. Was nation-building and homogenization the theme in the $19^{\text {th }}$ century in Western Europe, now tolerance for the other, for the deviant one is at the political forefront ${ }^{38}$. The Charter is a perfect example of this plea for tolerance. Now linguistic diversity is called a wealth and no longer a disadvantage or damage. Therefore, the European Charter promotes regional and minority languages. Whether this command is executed successfully is a topic for another study.

\section{References}

Act of 6 January 2005 on national and ethnic minorities and on the regional languages. Available at: http://ksng.gugik.gov.pl/english/files/act_on_national_minorities.pdf

Adoumié, Vincent. 2013². Géographie de la France. Paris: Hachette.

Barère, Bertrand. 1794. Rapport du Comité de salut public sur les idiomes. Retrieved 6.2.2018 from: www.axl.cefan.ulaval.ca/francophonie/barere-rapport.htm

Baumann, Richard and Charles L. Briggs. 2003. Voices of modernity: language ideology and the politics of inequality. Cambridge: Cambridge University Press.

Coulmas, Florian. 1995. "Germanness: language and nation". In: Stevenson, Patrick (ed.). The German language and the real world. Oxford: Oxford University Press. 55-68.

Elst, Annette van der and Florentijn van Rootselaar. 2014. Franse affaires, Frankrijk in twintig kwesties. Diemen: Veen Magazines.

\footnotetext{
${ }^{38}$ Unfortunately, a number of Central and Eastern European countries were only able to start their nation-building after the collapse of the Warsaw Pact. Respect for the deviant other is therefore a wish rather than a reality in some of these countries.
} 
European Charter for Regional and Minority Languages. 1992. European Treaty Series no. 148. Retrieved 12.11.2016 from: https://rm.coe.int/1680695175. Also available at https://www.coe.int/en/ web/conventions/full-list/-/conventions/rms/0900001680695175

Expert's Report Spain. 2005. Committee of Experts evaluation report Spain. Retrieved 12.11.2016 from: https://www.coe.int/t/dg4/education/minlang/Report/EvaluationReports/SpainECRML1_en.pdf

Explanatory Report to the European Charter for Regional and Minority Languages. 1992. European Treaty Series no. 148. Retrieved 12.11.2016 from: https://rm.coe.int/CoERMPublicCommonSearch Services/DisplayDCTMContent?documentId=09000016800cb5e5 also available at https://rm.coe.int/ $16800 \mathrm{cb} 5 \mathrm{e} 5$

Fenyvesi, Anna. 1998. "Linguistic minorities in Hungary". In: Bratt Paulston, Christina and Donald Peckham (eds.). Linguistic minorities in Central and Eastern Europe. Clevendon et. al.: Multilingual Matters. 135-159.

Forster, Michael (ed.). 2002. Herder: philosophical writings. Cambridge: Cambridge University Press.

Gregoire, Henri (Abbé). 1794. Rapport sur la nécessité et les moyens d'anéantir les patois et d'universaliser la langue française. Retrieved 6.2.2018 from: http://www.axl.cefan.ulaval.ca/fran cophonie/gregoire-rapport.htm

Gussenhoven, Carlos. 2000. "On the origin and development of the central Franconian tone contrast". In: Lahiri, Aditi (ed.). Analogy, levelling, markedness: principles of change in phonology and morphology. Berlin: Mouton de Gruyter. 215-260.

Hagen, A. (Toon), Stijnen, P.(Sjef) and A. (Ton) Vallen. 1975. Dialekt en onderwijs in Kerkrade. Nijmegen: NCDN/NIVOR.

Hamans, Camiel. 2006. "The minority language debate: the case of Yiddish in the Dutch language landscape". Werkwinkel 1. 225-252.

Hamans, Camiel. 2015. „The Charter at work”. Scripta Neophilologica Posnaniensia 15. 57-81.

Hamans, Camiel. 2016. "Language policy in the Netherlands". Scripta Neophilologica Posnaniensia 16. 41-61.

Hout, Roeland, Henk Bloemhoff, Leonie Cornips, Goffe Jensma and Joep Leerssen. 2018. Positiepaper: De positie van de erkende regionale talen in Nederland. Retrieved 14.3.2018 from: http://www. neerlandistiek.n1/2018/03/positie-paper-de-positie-van-de-erkende-regionale-talen-in-nederland/

Joseph, John. 2002. From Whitney to Chomsky. Essays in the history of American linguistics. Amsterdam and Philadelphia, PA: John Benjamins Publishing Company.

Kelly, Louis G. 1995. "History of translation". In: Koerner, E.F.K. and R.E. Asher. 419-430.

Kibbee, Douglas A. 1995. "Renaissance linguistics in France". In: Koerner, E.F.K. and R.E. Asher. 161-166.

Koerner, E.F. Konrad. 2001. "William Labov and the origins of sociolinguistics". Folia Linguistica Historic 22 (1-2). 1-40.

Koerner, E.F. Konrad and Ronald E. Asher. (eds.). 1995. Concise history of the language sciences. Oxford, New York and Tokyo: Pergamon.

Kroonenberg, Simon. 2014. De Binnenplaats van Babel. Het Raadsel van de Spraakverwarring. Amsterdam/Antwerpen: Contact.

Labov, William. 1969. The logic of nonstandard English. Washington: Georgetown University School of Languages and Linguistics.

Milroy, James. 2001. "Language ideologies and the consequences of standardization". Journal of Sociolinguistics 5 (4). 530-555.

Ó Riagáin, Dónall. 2001. "Many tongues but one voice: a personal overview of the role of The European Bureau for lesser used languages in promoting europe's regional and minority languages". In: O'Reilly, Camille (ed.). Language, ethnicity and the state. Volume 1: Minority languages in the European Union. Houndmills, Basingstoke: Palgrave. 20-39. 
Patten, Alan. 2010. "The most natural state: Herder and nationalism". History of Political Thought 31 (4). 657-689.

Perceval, W. Keith. 1995. "Renaissance linguistics: an overview". In: Koerner, E.F.K. and R.E. Asher. $147-151$.

Pisarek, Walery. 2011. "The relationship between official and minority languages in Poland". In: Stickel, Gerhard (ed.). National, regional and minority languages in Europe. Bern: Peter Lang. 117-122.

Poignant, Bernard. 1998. Rapport sur les langues et cultures régionales Retrieved 6.2.2018 from: http://www.axl.cefan.ulaval.ca/francophonie/Rapport-poignant-98.htm

Richardson, Brian. 1995. "Renaissance linguistics in Italy”. In: Koerner, E.F.K. and R.E. Asher. 152-156.

Stone, Gerald. 1998. „Cassubian”. In: Price, Glanville (ed.): Encyclopedia of the languages of Europe. Oxford: Blackwell. 49-50.

Trudgill, Peter. 1974. The social differentiation of English in Norwich. Cambridge: Cambridge University Press.

Von Hartungen, Christoph. 2002. A brief contemporary history of Alto Adige/Südtirol: (1918-2002). Translated into English by Vivienne Frankell. Bolzano: Consiglio.

Wal, Marijke van der and Cor van Bree. 1992. Geschiedenis van het Nederlands. Utrecht: Spectrum.

Watts, Richard J. 2012. "Language myths". In: Hernández-Campoy, Juan Manuel and Juan Camilo Conde-Silvestre (eds.): The handbook of historical sociolinguistics. Oxford: Blackwell. 585-606.

Winkels, Edwin. 2017. "50 jaar ETA: 800 doden en duizenden jaren gevangenisstraf", retrieved 18.4.2017 from https://nos.nl/artikel/2163720-50-jaar-eta-800-doden-en-duizenden-jaren-gevangenis straf.html 